\title{
POPULASI DAN KEANEKARAGAMAN CACING TANAH PADA BERBAGAI LOKASI DI HUTAN TAMAN NASIONAL BUKIT BARISAN SELATAN (TNBBS)
}

\author{
Berry Palito Simatupang, Ainin Niswati \& Sri Yusnaini \\ Jurusan Agroteknologi, Fakultas Pertanian, Universitas Lampung \\ Jl. Prof. Sumantri Brojonegoro 1 Bandar Lampung 35145 \\ E-mail: berrypalito@yahoo.co.id
}

\begin{abstract}
ABSTRAK
Taman Nasional Bukit Barisan Selatan (TNBBS) merupakan salah satu hutan di Indonesia yang memiliki keanekaragaman hayati yang cukup tinggi. Sebagai kawasan konservasi, TNBBS diharapkan dapat menjadi kawasan pemeliharaan dan perlindungan bagi keanekaragaman hayati yang secara tidak langsung berarti dapat melestarikan keanekaragaman jenis flora dan fauna yang terdapat di dalamnya, termasuk cacing tanah. Cacing tanah sendiri dapat menjadi indikator kelestarian hutan. Penelitian ini dilakukan menggunakan metode survey, yaitu dengan cara melihat kondisi lokasi penelitian dan pengumpulan data langsung dari beberapa lokasi di hutan TNBBS. Pengambilan sampel dilakukan di 3 lokasi, yaitu Bukit Camp Rhino, Bukit Kilometer 26, dan Pemerihan Kecil. Pengambilan sampel dilakukan di 3 lokasi, yaitu Bukit Camp Rhino, Bukit Kilometer 26, dan Pemerihan Kecil. Hasil survei menunjukkan bahwa populasi cacing tanah tertinggi terdapat di lokasi Pemerihan dan populasi terendah terdapat di lokasi Bukit Kilometer 26 (KM 26) bagian atas. Biomassa cacing tanah yang tertinggi terdapat di lokasi Bukit Camp Rhino bagian bawah dan biomassa terendah terdapat di lokasi Bukit Kilometer 26 (KM 26) bagian atas. Populasi dan biomassa cacing tanah berkorelasi positif dengan C-organik tanah, tetapi sifat kimia dan sifat fisik tanah yang lain tidak berkorelasi positif. Dari identifikasi cacing tanah hanya terdapat 2 famili cacing tanah, yaitu famili Megascolecidae dan famili Glossoscolecidae. Famili Glossoscolecidae hanya ditemukan di lokasi Pemerihan.
\end{abstract}

Kata Kunci: biomassa, cacing tanah, populasi, TNBBS

\section{PENDAHULUAN}

Di Indonesia hutan adalah salah satu ekosistem yang jumlahnya cukup luas, mencapai 130.609.014,98 Ha (Departemen Kehutanan, 2011). Ekosistem hutan menyimpan keanekaragaman hayati yang tinggi, terutama keanekaragaman flora dan fauna. Taman Nasional Bukit Barisan Selatan (TNBBS) merupakan salah satu cagar alam di Indonesia yang memiliki keanekaragaman hayati yang tinggi. Kawasan yang terletak di ujung selatan dari rangkaian pegunungan Bukit Barisan yang terdiri dari tipe vegetasi hutan mangrove, hutan pantai, hutan tanah tropika sampai pegunungan di Sumatera. Hutan-hutan yang ada di TNBBS sebagian besar tergolong ke dalam hutan hujan tropis. Taman Nasional Bukit Barisan Selatan merupakan aset Nasional yang harus dijaga kelestariannya (Indrawan, 1998). Indikator kelestarian hutan tersebut adalah keanekaragaman flora dan fauna baik yang hidup di atas tanah maupun di bawah tanah.

Berdasarkan peta tanah yang dibuat oleh Lembaga Penelitian Tanah Bogor, tanah dikawasan Taman Nasional Bukit Barisan Selatan terdiri dari 6 jenis tanah, yaitu alluvial, rensina, latosol, podsolik merah kuning, dan dua jenis andosol. Tanah yang paling luas tersebar adalah jenis podsolik merah kuning. Topografi di TNBBS yang cukup bervariasi yaitu mulai datar, landai, bergelombang, berbukit-bukit curam bergununggunung dengan ketinggian berkisar antara $0-1964 \mathrm{~m}$ dpl. Pengaruh rantai Pegunungan Bukit Barisan Selatan mengakibatkan kawasan ini memiliki dua tipe iklim (tipe iklim A di sisi barat taman nasional dan tipe iklim B yang lebih kering di sisi timur taman nasional). Di bagian barat taman nasional curah hujannya cukup, yaitu berkisar antara $3.000-3.500 \mathrm{~mm}$ per tahun dan bagian timur berkisar antara $2.500-3.000 \mathrm{~mm}$ per tahun. Kelembaban udara di TNBBS antara $80 \%$ sampai $90 \%$ dan temperatur berkisar antara $20^{\circ} \mathrm{C}-28^{\circ} \mathrm{C}$ (BTNBBS, 1999).

Perbedaan jenis tanah, topografi lahan, dan iklim sangat mempengaruhi keanekaragaman flora di TNBBS. Itu terbukti dengan adanya diversitas tanaman pada hutan tersebut. Jenis tanaman di taman nasional tersebut antara lain pidada (Sonneratia sp.), cempaka (Michelia champaka), nipah (Nypa fruticans), meranti (Shorea sp.), mersawa (Anisoptera curtisii), cemara laut 
(Casuarina equisetifolia), pandan (Pandanus sp.), ramin (Gonystylus bancanus), keruing (Dipterocarpus sp.), damar (Agathis sp.), rotan (Calamus sp.), dan bunga raflesia (Rafflesia arnoldi). Tumbuhan yang menjadi ciri khas taman nasional ini adalah bunga bangkai jangkung (Amorphophallus decussilvae), anggrek raksasa/tebu (Grammatophylum speciosum), dan bunga bangkai raksasa (A. titanum) (BTNBBS, 1999)

Keanekaragaman tanaman di TNBBS menyebabkan perbedaan jenis seresah pada masingmasing lokasi berdasarkan jenis tumbuhan yang hidup di atasnya. Hal ini tentu akan mempengaruhi organisme yang ada di dalam tanah. Salah satunya adalah cacing tanah yang merupakan organisme tanah yang hidupnya sangat dipengaruhi oleh keberadaan bahan organik di sekitarnya sebagai sumber energi. Cacing tanah merupakan salah satu fauna tanah yang penting dan dapat dijadikan indikator kelestarian tanah. Keragaman hayati cacing tanah merupakan ecosystem engineer yang berperan penting dalam mempengaruhi fungsi hidrologi tanah (Lavelle and Spain, 2001).

\section{BAHAN DAN METODE}

Tempat dan Waktu Penelitian. Penelitian ini dilaksanakan di Taman Nasional Bukit Barisan Selatan
(TNBBS). Penelitian ini dilakukan dari bulan Januari 2013 hingga Maret 2013. Analisis cacing tanah dilakukan di Laboratorium Bioteknologi Pertanian dan analisis contoh tanah dan seresah dilakukan di Laboratorium Ilmu Tanah, Fakultas Pertanian, Unversitas Lampung.

Pelaksanaan Penelitian. Pengambilan sampel dilakukan pada beberapa lokasi hutan di Taman Nasional Bukit Barisan Selatan. Secara geografis terletak antara $4^{\circ} 33^{\prime}-5^{\circ} 57^{\prime} \mathrm{LS}, 103^{\circ} 23^{\prime}-104^{\circ} 43^{\prime}$ BT. Terdiri dari tiga lokasi, yaitu Bukit Camp Rhino (530' 10.68" S $\left.104^{\circ} 25^{\prime} 45.62^{\prime \prime} \mathrm{E}\right)$ dengan ketinggian $600 \mathrm{~m}$ dpl terletak di Km 50 Taman Nasional Bukit Barisan Selatan (TNBBS), Bukit Kilometer 26 (5³1' 41.60" S - 104 25' 46.81" E) dengan ketinggian $569 \mathrm{~m}$ dpl, dan Bukit Pemerihan Kecil (5³6’27.97" S - 104 ${ }^{\circ} 24^{\prime} 16.21^{\prime \prime}$ E) dengan ketinggian $113 \mathrm{~m}$ dpl. Dari masing - masing lokasi, sampel diambil pada masing-masing lokasi yang dibedakan menjadi lokasi atas, tengah, dan bawah. Dari ketiga lokasi di tentukan 4 titik untuk pengambilan sampel (Gambar 1).

Sampel diambil pada masing-masing lokasi yang dibedakan menjadi lokasi atas, tengah, dan bawah. Dari ketiga lokasi di tentukan 4 titik untuk pengambilan sampel. Sampel cacing tanah diambil dengan membuat Monolith dengan luasan $50 \mathrm{~cm} \times 50 \mathrm{~cm}$ ditandai dengan rantai pembatas. Kemudian digali dengan kedalaman

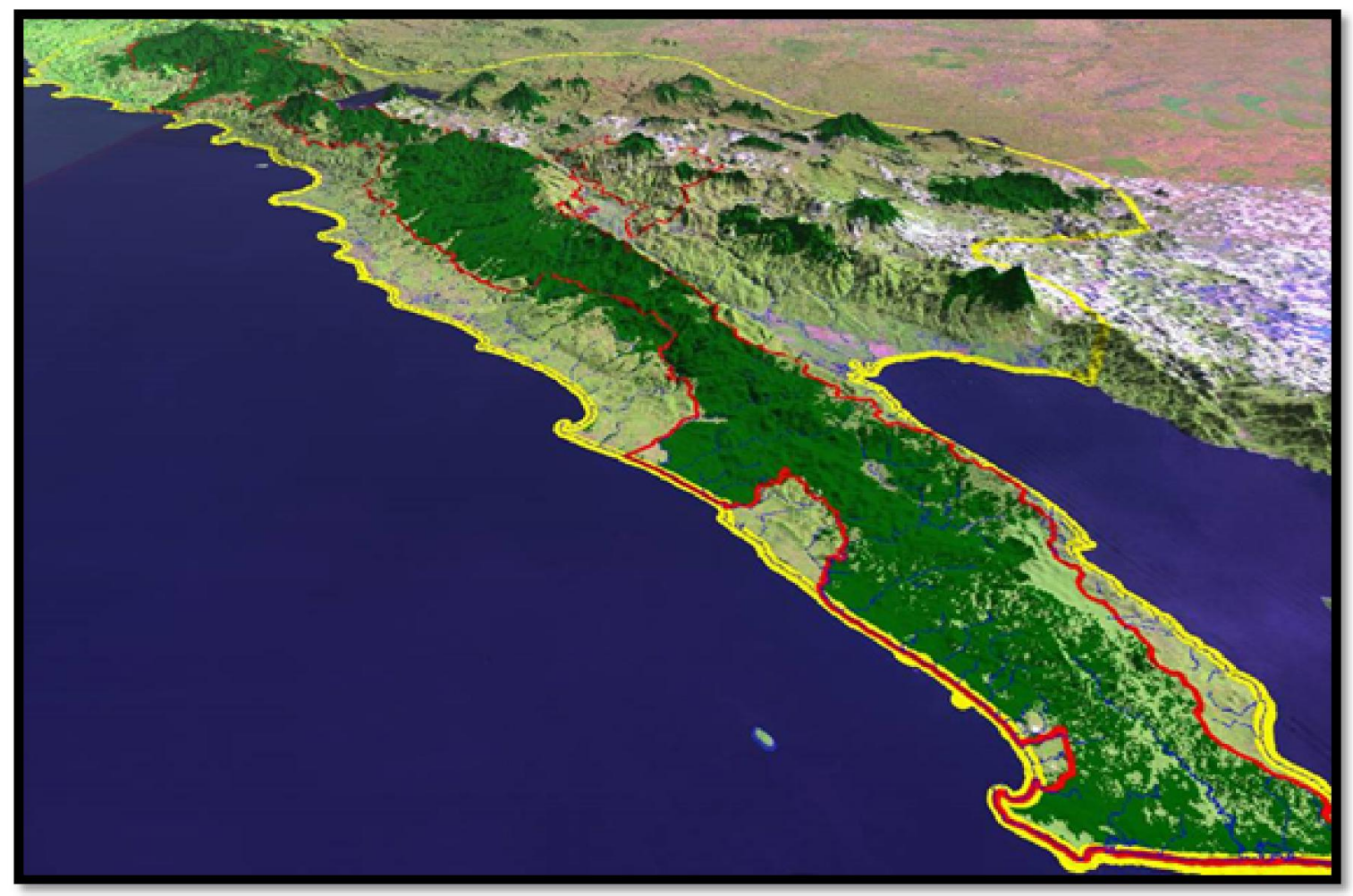

Gambar 1. Peta lokasi penelitian di Taman Nasional Bukit Barisan Selatan (TNBBS). 
$15 \mathrm{~cm}$. Dari tanah yang digali, cacing tanah diamati dan dihitung jumlahnya menggunakan metode penghitungan dengan tangan (hand sorting), yaitu dengan memisahkan cacing dari tanah satu persatu menggunakan tangan. Cacing tanah dihitung jumlahnya dan dispesifikasikan menjadi dewasa, anakan, potongan, dan kokon. Penghitungan pada bagian cacing yang berupa potongan diasumsikan menjadi $1 / 2$ bagian.

Cacing yang didapatkan ditaruh dalam botol plastik yang sudah diberi label. Kemudian botol diberi formalin agar cacing tidak busuk sampai dibawa di laboratorium untuk dihitung jumlahnya dan ditimbang menggunakan timbangan elekrik untuk memperoleh data biomassanya. Jenis - jenis cacing tanah yang diperoleh diidentifikasi berdasarkan letak klitelum dan bentuk setae pada cacing tanah sesuai dengan metode dari Blakemore (2002). Pengidentifikasian cacing tanah dapat dilakukan apabila cacing tanah yang didapatkan berumur cukup dewasa sehingga segmentasi dan letak klitellum sudah tampak jelas.

Uji korelasi dilakukan untuk mengetahui hubungan antara variabel utama (populasi dan biomassa cacing tanah) dengan variabel pendukung ( $\mathrm{pH}$ tanah, C-organik seresah (\%), C-organik tanah (\%), N-total tanah (\%), $\mathrm{N}$-total seresah (\%), kadar air tanah (\%), kadar air seresah (\%), suhu tanah $\left({ }^{\circ} \mathrm{C}\right)$, biomassa tanah $(\mathrm{g})$, dan biomassa seresah $(\mathrm{g})$.

\section{HASIL DAN PEMBAHASAN}

\section{Hasil}

Hasil survei menunjukkan bahwa populasi cacing tanah tertinggi terdapat di lokasi Pemerihan dan populasi terendah terdapat di lokasi Bukit Kilometer 26 (KM 26) bagian atas. Sedangkan biomassa cacing tanah yang tertinggi terdapat di lokasi Bukit Camp Rhino bagian bawah dan biomassa terendah terdapat di lokasi Bukit Kilometer 26 (KM 26) bagian atas (Tabel 1).

Berdasarkan uji korelasi pada Tabel 2, C-organik seresah, N - Total seresah, N-total tanah, $\mathrm{pH}$ tanah, suhu tanah, kadar air seresah, kadar air tanah, dan biomassa seresah tidak berkorelasi dengan populasi dan biomassa cacing tanah, sedangkan $\mathrm{C}$-organik tanah berkolerasi dengan populasi dan biomassa cacing tanah.

Dari hasil identifikasi cacing tanah yang dilakukan di laboratorium, terdapat 2 genus dari 2 famili yang berbeda, yaitu genus Pontoscolex (famili Glossoscolecidae) dan genus Pheretima (famili Megascolecidae) (Gambar 2). Pada saat identifikasi, ternyata tidak semua cacing tanah dapat diidentifikasi, karena terdapat beberapa cacing tanah yang belum memiliki klitelum sebagai penciri untuk menentukan jenis cacing tanah.

Cacing tanah dengan genus Pontoscolex sp. (famili Glossoscolecidae) merupakan cacing tanah yang klitelumnya berada pada segmen $14-20$ (Gambar 3) dan setae pada famili ini berpola lumbrisin (berpasangan erat) (Gambar 3), dengan panjang total tubuh berkisar antara 35-120 mm, diameter antara 2-4 $\mathrm{mm}$, jumlah segmen berkisar antara 83-215 segmen, warna bagian dorsal coklat kekuningan, warna bagian ventral abu-abu keputihan, warna ujung anterior kekuningan, dan warna ujung posterior coklat kekuningan. Sedangkan cacing tanah dengan genus Pheretima sp. (famili Megascolecidae) adalah cacing tanah yang klitelumnya terletak di depan segmen ke 15 (Gambar 3) dan setaenya berpola perisetin (berpasangan renggang) (Gambar 3).

Tabel 1. Populasi dan biomassa cacing tanah pada beberapa lokasi di Taman Nasional Bukit Barisan Selatan (TNBBS).

\begin{tabular}{ccc}
\hline Perlakuan & Populasi $\left({\left.\text { ekor } \mathrm{m}^{-2}\right)}\right.$ & Biomassa $\left(\mathrm{g} \mathrm{m}^{-2}\right)$ \\
\hline Camp Rhino & & \\
Atas & $33 \pm 18,86$ & $15,60 \pm 8,40$ \\
Tengah & $12 \pm 16,00$ & $2,85 \pm 3,56$ \\
Bawah & $53 \pm 19,77$ & $18,90 \pm 10,00$ \\
\hline Kilometer 26 & & \\
Atas & $6 \pm 4,00$ & $1,93 \pm 2,00$ \\
Bawah & $26 \pm 27,28$ & $7,97 \pm 8,60$ \\
\hline Pemerihan & $15 \pm 6,40$ & $11,40 \pm 4,55$ \\
\hline
\end{tabular}


Tabel 2. Ringkasan uji korelasi populasi dan biomassa cacing tanah dengan C-organik seresah, N-total seresah, pH tanah, suhu tanah, kadar air seresah dan biomassa seresah di hutan TNBBS.

\begin{tabular}{lcc}
\hline \multirow{2}{*}{ Variabel } & \multicolumn{2}{c}{ Nilai r } \\
\cline { 2 - 3 } & Populasi Cacing Tanah & Biomassa Cacing Tanah \\
\hline C- organik tanah & $0,48^{*}$ & $0,41^{*}$ \\
C-organik seresah & $-0,08^{\text {tn }}$ & $-0,10^{\text {tn }}$ \\
N-total tanah & $0,09^{\text {tn }}$ & $0,15^{\text {n }}$ \\
N-total seresah & $-0,17^{\text {tn }}$ & $-0,18^{\text {tn }}$ \\
C/N Ratio Tanah & $0,50^{* *}$ & $0,31^{\text {tn }}$ \\
C/N Ratio Seresah & $0,21^{\text {tn }}$ & $0,22^{\text {n }}$ \\
pH tanah & $0,15^{\text {tn }}$ & $0,27^{\text {tn }}$ \\
Suhu tanah & $0,16^{\text {tn }}$ & $0,04^{\text {tn }}$ \\
Kadar air tanah & $0,09^{\text {tn }}$ & $0,10^{\text {tn }}$ \\
Kadar air seresah & $0,21^{\text {tn }}$ & $0,22^{\text {tn }}$ \\
Biomassa seresah & $0,01^{\text {tn }}$ & $-0,06^{\text {tn }}$ \\
Populasi cacing tanah & - & $0,88^{* *}$ \\
\hline
\end{tabular}

Keterangan $: \mathrm{tn}=$ tidak berbeda nyata dalam taraf $5 \%, *=$ berbeda nyata dalam taraf $5 \%, * *=$ sangat berbeda nyata pada taraf $1 \%$

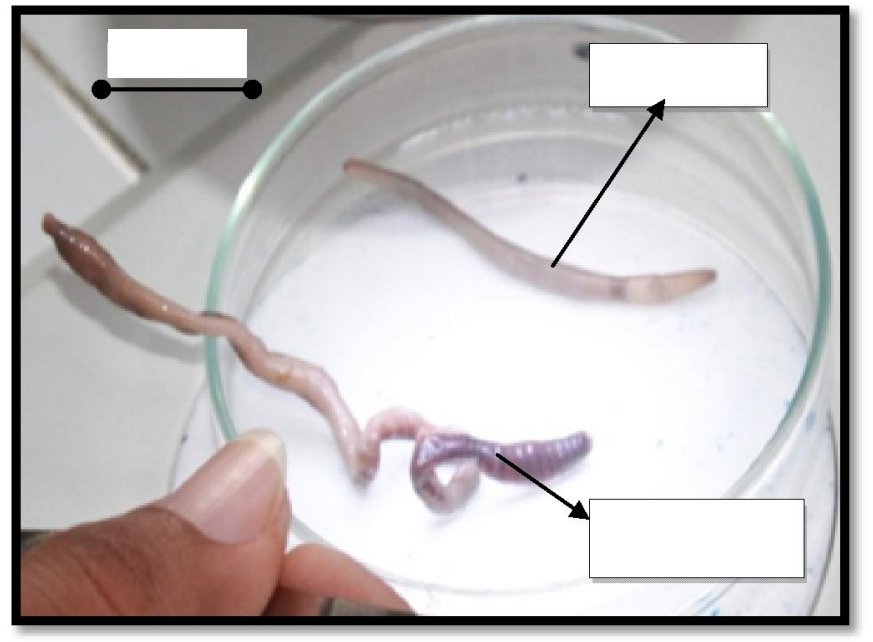

Gambar 2. Jenis-jenis cacing tanah hasil pengamatan di beberapa lokasi TNBBS
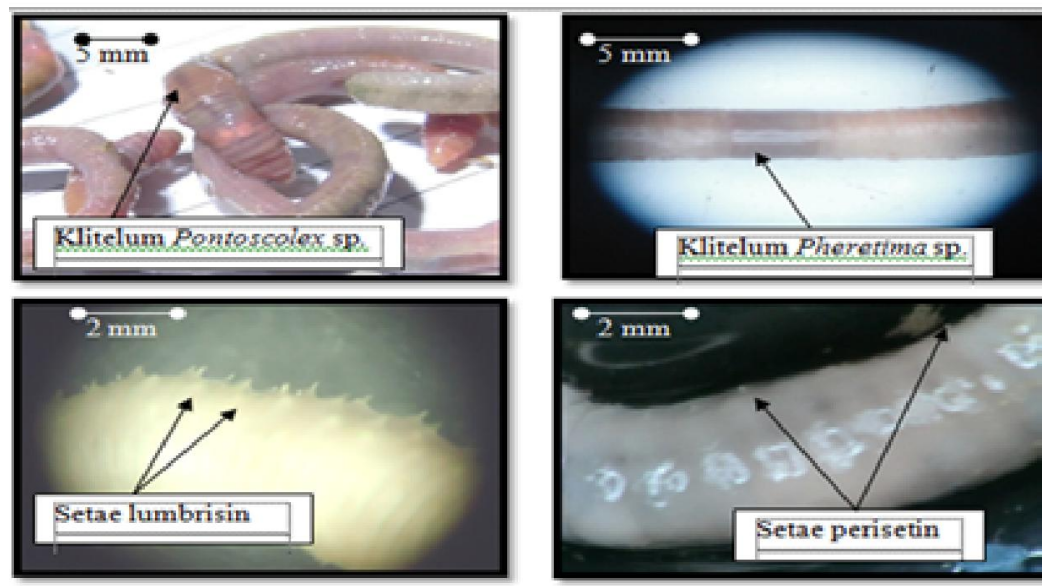

Gambar 3. Letak Klitelium dan Setae cacing tanah hasil pengamatan di beberapa lokasi TNBBS 


\section{Pembahasan}

Pada umumnya alih guna lahan hutan menjadi lahan pertanian baik monokultur maupun polikultur (campuran berbagai jenis pohon) akan menurunkan jumlah populasi cacing tanah (Hairiah dkk., 2004), tetapi pada penelitian ini justru hal sebaliknya terjadi yaitu bahwa terdapat beberapa lokasi hutan TNBBS yang populasi cacing tanahnya rendah. Populasi cacing tanah pada setiap lokasi menunjukkan variasi yang cukup tinggi. Populasi tertinggi di jumpai di lokasi Pemerihan, sedangkan populasi terendah dijumpai di Bukit Kilometer 26 bagian atas. Perbedaan tersebut dipengaruhi oleh berbedanya jenis tegakan yang mendominasi pada masing-masing lokasi. Lokasi Pemerihan didominasi oleh Rotan (Calamus sp.), Gelam (Melaleuca sp.), Jengkol (Pitchelobium jiringa), Dammar (Shorea javanica), Damar asam (Porinari sp.), sedangkan Bukit Kilometer 26 bagian atas didominasi oleh Duren hutan (Durio zibethinus), Bandotan (Heliatropium indicum), Daun cengkeh (Syzygium aromaticum), Keruing (Dipterocarpus elongatus).

Lokasi Pemerihan terletak di dekat pemukiman desa atau perkampungan dan diduga tanah di lokasi ini merupakan tanah yang terganggu sebagai hutan lindung dan di sekelilingnya terdapat kebun singkong yang diusahakan oleh petani setempat. Ini terbukti dengan hanya ditemukannya cacing tanah dengan genus Pontoscolex sp. (famili Glossoscolecidae) di lokasi Pemerihan. Ini sejalan dengan hasil penelitian Dewi et al. (2006) di Sumberjaya, Lampung, dimana Pontoscolex tidak ditemukan pada hutan alami. Pontoscolex merupakan jenis cacing penggali tanah yang berasal dari Brazilia yang tahan hidup pada kondisi lingkungan yang beragam mulai dari lahan terdegradasi (padang lalang), lahan kopi monokultur, agroforestri berbasis kopi hingga hutan alami yang telah terganggu.

Sedangkan pada Bukit Kilometer 26 bagian atas memiliki populasi terendah dibanding dengan lokasilokasi yang lain. Rendahnya populasi cacing tanah di lokasi ini diduga dipengaruhi oleh adanya dominasi vegetasi Daun cengkeh (Syzygium aromaticum) yang seresahnya mengandung tanin. Menurut Catalan (1981) cacing tanah tidak menyukai serasah daun yang mengandung tanin atau minyak seperti daun cengkeh, pinus dan jeruk. Tanin bersifat toksik bagi cacing tanah.

Populasi cacing tanah di lokasi Pemerihan memang yang teringgi, namun untuk biomassa cacing tanah yang tertinggi bukanlah di lokasi Pemerihan melainkan di lokasi Camp Rhino bagian bawah dengan rata-rata biomassa cacing 19,05 $\mathrm{g} \mathrm{m}^{-2}$. Sedangkan biomassa cacing tanah yang paling rendah ada di Bukit Kilometer 26 bagian atas. Hal ini sejalan dengan penelitian Valentina (2013) bahwa lokasi Bukit Kilometer 26 bagian atas dipenuhi oleh seresah yang kaya akan serat sehingga menyebabkan lamanya proses dekomposisi yang membuat ketersediaan sumber energi dan nutrisi bagi fauna tanah terjamin lebih lama tersedia sehingga fauna tanah tidak bertahan di lokasi tersebut.

Berdasarkan hasil uji korelasi, tidak ada korelasi antara populasi dan biomassa cacing tanah dengan sifat kimia dan fisik tanah maupun seresah kecuali C-organik tanah. Hal ini menunjukkan bahwa C-organik sangat penting bagi keberlangsungan hidup cacing tanah karena menurut Hanafiah dkk. (2005), distribusi bahan organik tanah berpengaruh terhadap cacing tanah karena terkait dengan sumber nutrisinya sehingga pada tanah miskin bahan organik hanya sedikit jumlah cacing tanah yang dijumpai.Rata-rata C-organik tanah tertinggi terdapat di lokasi Camp Rhino bagian bawah yaitu 2,39\% dan ditemukan rata-rata cacing tanah 60 ekor $\mathrm{m}^{-2}$ dengan biomassa tertinggi yaitu $19,05 \mathrm{~g} \mathrm{~m}^{-2}$. Sedangkan Corganik terendah terdapat di lokasi Bukit Kilometer 26 bagian bawah yaitu $1,20 \%$ dan hanya ditemukan cacing tanah 16 ekor $\mathrm{m}^{-2}$ dengan biomassa $11,40 \mathrm{~g} \mathrm{~m}^{-2}$.

Berbeda dengan $\mathrm{C}$-organik tanah, $\mathrm{C}$-organik seresah dan $\mathrm{N}$-total seresah tidak berkorelasi nyata terhadap populasi dan biomassa cacing tanah di beberapa lokasi TNBBS. Hal ini dapat disebabkan karena cacing tanah yang terdapat di TNBBS adalah cacing tanah endogeic yaitu cacing tanah yang hidup di dalam tanah dan memakan bahan organik yang ada pada tanah, sehingga $\mathrm{C}$-organik seresah maupun $\mathrm{N}$-total seresah yang belum terserap di dalam tanah tidak dapat di makan oleh cacing tanah. Cacing tanah yang memperoleh makanannya dari seresah di permukaan tanah adalah dari kelompok anecic yang bergerak aktif dalam tanah baik secara horizontal maupun vertikal (Fragoso dkk., 1997, dalam Hairiah dkk., 2002).

Hasil uji korelasi antara N-total tanah dengan populasi dan biomassa cacing tanah sama-sama menunjukan tidak adanya korelasi nyata. N-total tanah tertinggi terdapat di lokasi Camp Rhino bagian atas yaitu $0,76 \%$ dan di lokasi tersebut ditemukan populasi cacing tanah 33 ekor $\mathrm{m}^{-2}$ dengan biomassanya $15,60 \mathrm{~g} \mathrm{~m}^{-2}$. Populasi dan biomassa cacing tanah di lokasi tersebut lebih rendah dari pada populasi dan biomassa cacing tanah di lokasi Camp Rhino bagian bawah, dimana di lokasi Camp Rhino bagian bawah N-total tanahnya hanya $0,54 \%$ namun terdapat populasi cacing tanah yang lebih tinggi yaitu 53 ekor $\mathrm{m}^{-2}$ dengan biomassa 19,05 g $\mathrm{m}^{-2}$. Hal ini diduga disebabkan oleh $\mathrm{pH}$ tanah di lokasi Camp Rhino bagian atas yang terlalu asam untuk cacing tanah yaitu 5,87 sedangkan $\mathrm{pH}$ tanah di Camp Rhino bagian bawah adalah 6,07. Menurut Budiarti dan 
Palungkun (1992), cacing tanah memerlukan pakan atau media dengan $\mathrm{pH}$ antara 6,0 sampai 7,2, karena pada $\mathrm{pH}$ tersebut bakteri bekerja optimal.

Dari hasil pengukuran $\mathrm{C} / \mathrm{N}$ ratio tanah, kita dapat melihat nisbah $\mathrm{C} / \mathrm{N}$ yang relatif rendah di setiap lokasi penelitian. Hal ini juga yang mempengaruhi banyak atau sedikitnya jumlah cacing tanah yang ada di lokasi tersebut. Dan itu dapat kita lihat dari hasil korelasi $\mathrm{C} / \mathrm{N}$ Ratio tanah dengan populasi cacing tanah yang menunjukkan adanya korelasi positif antara $\mathrm{C} / \mathrm{N}$ ratio tanah dengan populasi cacing tanah. Karena menurut Tian (1994), cacing tanah lebih menyukai bahan organik yang berkualitas tinggi atau memiliki nisbah $\mathrm{C} / \mathrm{N}$ rendah. Sedangkan $\mathrm{C} / \mathrm{N}$ ratio seresah yang ada di lokasi penelitian relatif lebih tinggi dari pada $\mathrm{C} / \mathrm{N}$ ratio tanah yaitu berkisar antara 14-18. Namun seresah ini masih dapat dikategorikan berkualitas tinggi karena menurut Handayanto (1994), seresah yang berkualitas tinggi adalah seresah yang mempunyai nisbah $\mathrm{C} / \mathrm{N}<20$.

Kadar air seresah tidak berkorelasi nyata dengan populasi dan biomassa cacing tanah di TNBBS. Hal ini diduga disebabkan oleh berbedanya jenis seresah dari masing-masing lokasi sehingga mempengaruhi kualitas dari bahan organik yang dihasilkan oleh seresah tersebut. Kadar air seresah sangat mempengaruhi cepat lambatnya seresah tersebut terdekomposisi. Menurut Hairiah et al. (2000). Tingkat penutupan (tebal tipisnya) lapisan seresah pada permukaan tanah berhubungan erat dengan laju dekomposisinya (pelapukannya). Semakin lambat terdekomposisi maka keberadaannya di permukaan tanah menjadi lebih lama. Sama halnya dengan kadar air seresah, kadar air tanah juga sangat berpengaruh terhadap proses dekomposisi bahan organik yang ada di dalam tanah. Tidak adanya korelasi yang nyata dari uji korelasi kadar air seresah dan kadar air tanah terhadap populasi dan biomassa cacing tanah diduga disebabkan oleh waktu pengambilan sampel yang dilakukan pada saat musim penghujan. Dari hasil penelitian dapat dilihat bahwa kadar air tanah di TNBBS sangat tinggi yaitu diatas 30\%. Menurut Simanjuntak dan Waluyo (1982), kelembaban yang baik untuk pertumbuhan dan perkembangbiakan cacing tanah adalah antara $15 \%$ sampai $30 \%$. Pada saat terjadi hujan, pukulan air hujan pada tanah yang terbuka dapat meningkatkan kerusakan agregat tanah, sehingga porositas tanah akan berkurang dan cacing tanah akan pergi mencari tanah dengan porositas tinggi untuk memudahkan sistem pernafasan di dalam tanah.

Menurut Sulistiyanto et al. (2005), cacing tanah umumnya memakan serasah daun dan juga materi tumbuhan lainnya yang telah mati, kemudian dicerna dan dikeluarkan berupa kotoran. Namun dari hasil penelitian ini, biomassa seresah tidak berkorelasi nyata dengan populasi dan biomassa cacing tanah. Ini dipengaruhi oleh kemampuan cacing tanah dalam mengkonsumsi serasah sebagai makanannya yang juga bergantung pada ketersediaan jenis serasah yang disukainya, disamping itu juga ditentukan oleh kandungan karbon dan nitrogen serasah sebagai nutrisi bagi cacing tanah.

\section{KESIMPULAN}

Berdasarkan penelitian yang telah dilakukan maka dapat dismpulkan sebagai berikut: (1) Populasi cacing tanah tertinggi terdapat di lokasi Pemerihan dan populasi terendah terdapat di lokasi Bukit Kilometer 26 bagian atas; (2) Biomassa cacing tanah tertinggi terdapat di lokasi Bukit Camp Rhino bagian bawah sedangkan biomassa cacing tanah terendah terdapat di lokasi Bukit Kilometer 26 bagian atas; (3) Populasi dan biomassa cacing tanah berkorelasi positif dengan C-organik tanah, tetapi sifat kimia dan sifat fisik tanah yang lain tidak berkorelasi positif; (4) Terdapat 2 famili cacing tanah yang didapat dari hasil identifikasi, yaitu famili Megascolecidae dan famili Glossoscolecidae.

\section{DAFTAR PUSTAKA}

Anas, I. 1990. Biologi Tanah dalam Praktek. Departemen Pendidikan dan Kebudayaan Direktorat Jendral Pendidikan Tinggi Pusat antar Universitas Bioteknologi. Institut Pertanian Bogor. $161 \mathrm{hlm}$

Balai Taman Nasional Bukit Barisan Selatan (BTNBBS). Rencana Pengelolaan Taman Nasional Bukit Barisan Selatan, Buku II. Taman Nasional Bukit Barisan Selatan, Kotaagung, Lampung. Tidak dipublikasikan.

Blakemore, R. J. 2002. Cosmopolitan Earthworms - an Eco-Taxonomic Guide to the Peregrine Species of the World. VermEcology, Kippax. Australia. $426 \mathrm{hlm}$.

Budiarti, A. dan R. Palungkun. 1992. Cacing Tanah: Aneka Cara Budidaya, Penanganan Lepas Panen, Peluang Campuran Ransum Ternak dan Ikan. Penebar Swadaya. Jakarta.

Catalan, G.I. 1981. Earthworms a New- Resource of Protein. Philippine Earthworms center. Philippines 
Hairiah, K., Purnomosidhi, N. Khasanah, N. Nasution, B. Lusiana, dan M.V. Noordwijk. 2003. Pemanfaatan Bagas dan Daduk Tebu untuk Perbaikan Status Bahan Organik Tanah dan Produksi Tebu di Lampung Utara: Pengukuran dan Estimasi Simulasi WANULCAS. Agrivita 25: $30-40$.

Hanafiah, K. A., I. Anas, A. Napoleon, dan N. Goffar. 2005. Biologi Tanah Ekologi Dan Makrobiologi Tanah. PT Raja Grafindo Persada. Jakarta. 157 hlm.

Handayanto, E .1994. Nitrogen Mineralization from Legume tree prunings of Different Quality. Thesis for Doctor of Phylosophy. Wye College, University of London.

Lavelle, P. Dan A. V. Spain. 2001. Soil Ecology. Kluwer Academic Publ., Dordrecht.

Lee, K.E. 1985. Earthworms, Their Ecology and Relationships with Soils and Land Use. Academic Press. London.
Sulistiyanto, Y., J. O. Rieley, dan S. H. Limin. 2005. Laju Dekomposisi Dan Pelepasan Hara Dari Serasah Pada Dua Sub-Tipe Hutan Rawa Gambut Di Kalimantan Tengah [The rate of decomposition and nutrients' release from litters in two sub-types peat swamp forests in Central Kalimantan]. Artikel. Jurnal Manajemen Hutan Tropika Vol. XI No. 2 : 1-14.

Tian, G. 1992. Biological Effects of Plant Residues with Contrasting Chemical Compositions on Plant and Soil under Humid Tropical Conditions. PhD Thesis. Wageningen Agricultural University, The Netherlands. 144 hlm.

Valentina, D.A. 2013. Populasi dan Keanekaragaman Mesofauna Tanah dan Seresah di Hutan Taman Nasional Bukit Barisan Selatan (TNBBS). Skripsi Fakultas Pertanian Universitas Lampung: Bandar Lampung. 50 